\title{
Comparative study of various oxytocics in management of third stage of labour
}

\author{
Shrinivas N. Gadappa, Deepika Sharma*, Yogita Gavit
}

Department of Obstetrics and Gynecology, Government Medical College and Hospital, Aurangabad, Maharashtra, India

Received: 18 July 2018

Accepted: 28 August 2018

*Correspondence:

Dr. Deepika Sharma,

E-mail: drdeepikasharma03@gmail.com

Copyright: (c) the author(s), publisher and licensee Medip Academy. This is an open-access article distributed under the terms of the Creative Commons Attribution Non-Commercial License, which permits unrestricted non-commercial use, distribution, and reproduction in any medium, provided the original work is properly cited.

\begin{abstract}
Background: Causes of maternal mortality are haemorrhages, infections, unsafe abortions, and obstructed labour. $25 \%$ of these are caused by haemorrhages and are preventable, one of the measures is active management of third stage of labour (AMTSL). For prevention, treatment of postpartum haemorrhage oxytocics are available oxytocin, methylergometrine, misoprostol, prostaglandin F2 $\alpha$.

Methods: Study was conducted, 160 patients were randomly given one of following oxytocics a) tablet misoprostol $600 \mu \mathrm{g}$ per rectal b) Inj. Oxytocin $10 \mathrm{IU}$ IM c) Inj. Methylergometrine $0.2 \mathrm{mg}$ IM d) Inj. PGF2 $\alpha$. Duration for the delivery of placenta and amount of blood loss was measured, side effects were noted, and comparison of haemoglobin and blood loss done.

Results: No significant difference in mean blood loss in all group with respect to parity and type of labour. In present study it seems that no oxytocic is superior to other in reducing the blood loss. Misoprostol has variable onset of action. Mean duration of $3^{\text {rd }}$ stage in various groups is same. In respect to side effects HTN is common with methylergometrine, shivering and fever with misoprostol and diarrhoea with PGF2 $\alpha$.

Conclusions: Study concluded that all uterotonics have some advantages, oxytocin is ultimate drug of choice in skilled hand due to its definite onset of action while Tab misoprostol in unskilled hands, other oxytocin are reserved for complementary usage and treatment of PPH but Misoprostol has variable onset of action.
\end{abstract}

Keywords: Active management of $3^{\text {rd }}$ stage of labor, Oxytocics, Postpartum hemorrhage

\section{INTRODUCTION}

The leading causes of maternal mortality are hemorrhage, Infection, Hypertension, unsafe abortion and obstructed labour ${ }^{1}$. One quarter of these deaths are caused by hemorrhage and are preventable by simple measures; one of them is Active Management of Third Stage of Labor (ATMSL). Active management of third stage of labor is an effective measure to prevent $\mathrm{PPH}$. According to WHO the components of active management of third stage of labor are: ${ }^{2}$
1. Administration of an oxytocic agent within one minute after delivery of baby.

2. Delayed cord clamping.

3. Delivery of placenta by control cord traction.

4. Uterine Massage.

For prevention and treatment of postpartum hemorrhage various oxytocics are available e.g. Oxytocin, Methylergometrine, Misoprostol, Prostaglandins F2 $\alpha$. Various randomized controlled trials have been carried out to determine the efficacy drugs. 
Considering the prime role of oxytocics in prevention of postpartum hemorrhage, the present study was carried out to see the role of these oxytocics and compare the efficacy of these drugs in management of third stage of labor.

The aims and objectives are to compare the efficacy of the four oxytocics i.e. Misoprotol, Oxytocin, Methylergometrine and PGF2 $\alpha$, to study the average blood loss in the third stage of labor and to study the side effects of the above-mentioned drugs.

\section{METHODS}

It was randomized clinical trial carried out at tertiary care institute for 3 years and sample size was 160 patients.

\section{Inclusion criteria}

- All low risk term pregnant women presenting to department of obstetrics and gynecology of present institute.

- Patients should be willing to be medicated with various oxytocics.

- $\quad$ Patients should be willing to remain admitted for 24 hours after delivery.

- Consent for surgical procedures implied, counseled for and accepted in case of failure or excessive bleeding.

- Patients should be willing to do hemoglobin estimation pre and post-delivery.

\section{Exclusion criteria}

- Patients with hemoglobin $<8$ gm $\%$.

- Patient landing in traumatic PPH.

- Pre-eclampsia and eclampsia.

- Grand multipara.

- Multiple pregnancy.

- Hydramnios, malpresentation.

- Antepartum eclampsia.

- Coagulation abnormalities.

- Medical disorders during pregnancy.

- Previous caesarian section.

Total 160 patients were studied, written valid informed consent was taken. Each of them was randomly given one of the following oxytocics within 1 minute to WHO protocol i.e. after vaginal delivery of baby and accordingly included in the particular oxytocic group such that equal number of patients were included in all groups.

- Group A: patients received Tab Misoprostol 600 mcg per rectally after the delivery of baby.

- Group B: patients received Inj. Oxytocin 10 IU intramuscular after the delivery of baby.

- Group C: patients received Inj. Methylergometrine $0.2 \mathrm{mg}$ intramuscular after the delivery of baby

- Group D: patients received Inj. PGF2 $\alpha 250 \mu \mathrm{g}$ after delivery of baby.

After administration of drugs, the time required for delivery of placenta was noted and amount of blood loss in each patient was measured. Side effects whichever occurred were noted.

No serious side effects occurred in the study. Comparison of pre and post-delivery haemoglobin and blood loss in each group was studied.

\section{Statistical analysis}

Mean and standard deviation was calculated, and statistical analysis carried out using Open Epi Software and using ANOVA test. Statistical significance was then calculated.

\section{RESULTS}

The average blood loss in Group A, B, C, D was $320.75 \pm 233.54, \quad 319.5 \pm 180.19, \quad 322.5 \pm 196.06$, $318.5 \pm 124.68 \mathrm{ml}$ respectively and the difference was statistically non-significant. There was no significant difference in mean blood loss in all oxytocic groups $(\mathrm{p}>0.05)$.

As we can see in primigravida patient percentage of cases having more blood loss in group $\mathrm{A}, \mathrm{B}, \mathrm{C}$ and $\mathrm{D}$ was $32.5 \%, 35.5 \%, 32.5 \%$ and $20 \%$ respectively.

They are almost equal in group A, B and C but slightly lesser in group D and $\mathrm{p}$ value was also not significant. Similarly amount of mean blood loss was also same with not significant $\mathrm{p}$ value.

Same results are seen in second, third and fourth gravida patients. So, there was no significant difference in amount of mean blood loss in all groups with respect to parity $(\mathrm{p}>0.05)$.

Table 1: Comparison of mean blood loss in all groups.

\begin{tabular}{|llllll|}
\hline & Group A $(n=40)$ & Group B $(n=40)$ & Group C $(n=40)$ & Group D (n=40) & P value \\
\hline Blood loss mean \pm SD $(\mathrm{ml})$ & $320.75 \pm 233.54$ & $319.5 \pm 180.19$ & $322.5 \pm 196.06$ & $318.5 \pm 124.68$ & 0.99 \\
\hline
\end{tabular}


Table 2: Comparison of parity to mean blood loss in all groups.

\begin{tabular}{|c|c|c|c|c|c|c|c|c|c|}
\hline \multirow[t]{2}{*}{ Parity } & \multicolumn{2}{|c|}{$\begin{array}{l}\text { Group A }(\mathrm{n}=40) \\
\text { case }(\%)\end{array}$} & \multicolumn{2}{|c|}{$\begin{array}{l}\text { Group B }(n=40) \\
\text { case }(\%)\end{array}$} & \multicolumn{2}{|c|}{$\begin{array}{l}\text { Group C }(n=40) \\
\text { case }(\%)\end{array}$} & \multicolumn{2}{|c|}{$\begin{array}{l}\text { Group D }(n=40) \\
\text { case }(\%)\end{array}$} & \multirow[t]{2}{*}{$\begin{array}{l}\mathbf{P} \\
\text { value }\end{array}$} \\
\hline & $\begin{array}{l}\text { Cases } \\
(\%)\end{array}$ & $\begin{array}{l}\text { Blood loss } \\
(\mathrm{ml})\end{array}$ & $\begin{array}{l}\text { Cases } \\
(\%)\end{array}$ & $\begin{array}{l}\text { Blood loss } \\
(\mathrm{ml})\end{array}$ & $\begin{array}{l}\text { Cases } \\
(\%)\end{array}$ & $\begin{array}{l}\text { Blood loss } \\
(\mathrm{ml})\end{array}$ & $\begin{array}{l}\text { Cases } \\
(\%)\end{array}$ & $\begin{array}{l}\text { Blood loss } \\
(\mathrm{ml})\end{array}$ & \\
\hline Para 1 & $\begin{array}{l}13 \\
(32.5)\end{array}$ & $319.23 \pm 265.75$ & $\begin{array}{l}14 \\
(35.5)\end{array}$ & $321.53 \pm 156.35$ & $13(32.5)$ & $318 \mathrm{~V} 141.34$ & $8(20)$ & $315 \pm 58.54$ & 0.99 \\
\hline Para 2 & $\begin{array}{l}21 \\
(52.5)\end{array}$ & $320 \pm 242.81$ & $\begin{array}{l}21 \\
(52.5)\end{array}$ & $320 \pm 234.73$ & $19(47.5)$ & $319.52 \pm 221.41$ & $26(65)$ & $321.15 \pm 148.54$ & 0.99 \\
\hline Para 3 & $4(10)$ & $320 \pm 170.29$ & $3(7.5)$ & $330 \pm 200.29$ & $6(15)$ & $330 \pm 112.69$ & $3(7.5)$ & $316.6 \pm 81.44$ & 0.99 \\
\hline Para 4 & $2(5)$ & $340 \pm 113.13$ & $2(5)$ & $320 \pm 113.13$ & $2(5)$ & $310 \pm 14.14$ & $3(7.5)$ & $306.66 \pm 68.06$ & 0.976 \\
\hline $\mathrm{P}$ value & 0.99 & & 0.99 & & 0.99 & & 0.99 & & \\
\hline
\end{tabular}

Table 3: Comparison of spontaneous and induced labour to mean blood loss in all groups.

\begin{tabular}{|c|c|c|c|c|c|c|}
\hline $\begin{array}{l}\text { Types of } \\
\text { labour }\end{array}$ & $\begin{array}{l}\text { Group A }(n=40) \\
\text { case }(\%)\end{array}$ & $\begin{array}{l}\text { Group B }(n=40) \\
\text { case }(\%)\end{array}$ & $\begin{array}{l}\text { Group C }(n=40) \\
\text { case }(\%)\end{array}$ & $\begin{array}{l}\text { Group D }(n=40) \\
\text { case }(\%)\end{array}$ & $\begin{array}{l}\text { Total } \\
\text { cases }(\%)\end{array}$ & $\begin{array}{l}P \\
\text { value }\end{array}$ \\
\hline $\begin{array}{l}\text { Spont- } \\
\text { aneous }\end{array}$ & $\begin{array}{ll}29 & 316.20 \pm 225.49\end{array}$ & $\begin{array}{ll}33 & 314.84 \pm 185.39\end{array}$ & $\begin{array}{l}32 \\
(80)\end{array} \quad 317 \pm 209.37$ & $\begin{array}{ll}28 & 313.57 \pm 143.79 \\
(70)\end{array}$ & $\begin{array}{l}122 \\
(76.25)\end{array}$ & 0.99 \\
\hline Induced & $\begin{array}{ll}11 & 332.7 \pm 264.84\end{array}$ & $\begin{array}{l}7 \\
(17.5)\end{array} 314.42 \pm 164.56$ & $\begin{array}{ll}8 & 342.5 \pm 139.46\end{array}$ & $\begin{array}{l}12 \\
(30)\end{array} 330 \pm 64.52$ & $\begin{array}{l}38 \\
(23.75)\end{array}$ & 0.99 \\
\hline$P$ value & 0.844 & 0.727 & 0.751 & 0.707 & & \\
\hline
\end{tabular}

In the present study, 122 patients $(76.25 \%)$ had spontaneous onset of labor and 38 patients $(23.75 \%)$ required induction of labor but there was practically no significant difference in amount of mean blood loss in each group irrespective of whether the labor was spontaneous or induced $(\mathrm{p}>0.05)$.

Table 4: Comparison of pre and post-delivery difference in mean haemoglobin in all groups.

\begin{tabular}{|c|c|c|c|c|c|}
\hline $\begin{array}{l}\text { Difference in Hb: } \\
\text { mean } \pm \text { SD }(\mathrm{g} \%)\end{array}$ & $\begin{array}{l}\text { Group A }(n=40) \\
\text { case }(\%)\end{array}$ & $\begin{array}{l}\text { Group B }(n=40) \\
\text { case }(\%)\end{array}$ & $\begin{array}{l}\text { Group C ( }(\mathrm{n}=40) \\
\text { case }(\%)\end{array}$ & $\begin{array}{l}\text { Group D }(n=40) \\
\text { case }(\%)\end{array}$ & P value \\
\hline & $1.54 \pm 1.01$ & $1.7 \pm 0.83$ & $1.68 \pm 0.98$ & $1.59 \pm 0.59$ & 0.84 \\
\hline
\end{tabular}

Mean haemoglobin in groups $\mathrm{A}, \mathrm{B}, \mathrm{C}$ and $\mathrm{D}$ pre-delivery was $9.86 \pm 1.13,10 \pm 1.14,10.07 \pm 1.17$ and $9.71 \pm 0.89$ respectively. Similarly, post-delivery haemoglobin was $8.32 \pm 0.72,8.32 \pm 0.85,8.4 \pm 0.9$ and $8.09 \pm 0.61$. The difference in pre and post-delivery mean hemoglobin in group A, B, C, D was $1.54 \pm 1.01,1.7 \pm 0.83,1.68 \pm 0.98$, $1.59 \pm 0.59$ respectively and the difference was statistically non-significant $(\mathrm{p}>0.05)$ which indicate that blood loss may be not significant.

Table 5: Average duration of third stage of labour in all groups.

\begin{tabular}{|lllllll} 
& $\begin{array}{l}\text { Group A }(n=40) \\
\text { case }(\%)\end{array}$ & $\begin{array}{l}\text { Group B (n=40) } \\
\text { case }(\%)\end{array}$ & $\begin{array}{l}\text { Group C (n=40) } \\
\text { case (\%) }\end{array}$ & $\begin{array}{l}\text { Group D (n=40) } \\
\text { case (\%) }\end{array}$ & P value \\
III Stage duration (minutes) & $4.925 \pm 1.89$ & $4.85 \pm 2.52$ & $4.825 \pm 2.13$ & $4.9 \pm 2.1$ & 0.99 \\
\hline
\end{tabular}

Average duration of third stage was calculated in all patients in all groups mean duration of third stage was $4.925 \pm 1.89,4.85 \pm 2.52,4.825 \pm 2.13$ and $4.9 \pm 2.1$. There was no significant difference in duration of third stage of labor in all groups $(\mathrm{p}>0.05)$. This might indicate that use of oxytocics in third stage might change the duration of third of stage as compared to no use of oxytocics but type of oxytocics has no effect on duration of third stage of labour. 
Table 6: Patients requiring additional oxytocics in each group.

\begin{tabular}{|llllll} 
& $\begin{array}{l}\text { Group A }(n=40) \\
\text { case }(\%)\end{array}$ & $\begin{array}{l}\text { Group B }(n=40) \\
\text { case }(\%)\end{array}$ & $\begin{array}{l}\text { Group C (n=40) } \\
\text { case }(\%)\end{array}$ & $\begin{array}{l}\text { Group D }(n=40) \\
\text { case }(\%)\end{array}$ & $\begin{array}{l}\text { Total cases } \\
(\%)\end{array}$ \\
\hline Use of additional oxytocics & $18(45)$ & $7(17.5)$ & $9(22.5)$ & $6(15)$ & $40(25)$
\end{tabular}

In the present study, total 40 patients out of $160(25 \%)$ required additional oxytocics to decrease third stage blood loss. Out of these 18, 7, 9 and 6 patients were from group A, B, C and D respectively. Maximum number of patients from Group A require additional oxytocic due to variability of absorption. In present study, total 14 patients had nausea post-delivery out of which 9 patients had vomiting. It was seen more in Group C; 14 patients had shivering out of which 8 patients were from Group A. Total 13 patients had fever postpartum out of which 8 belongs to group A all those patients have associated shivering. Five patients had diarrhea in which 3 were from Group D which is significant. Headache was observed in 10 patients with almost equal distribution in each group. Total 9 patients had hypertension out of which 5 were from Group C.

Table 7: Adverse effect profile in all groups.

\begin{tabular}{|llllll|}
\hline & $\begin{array}{l}\text { Group A }(\mathrm{n}=40) \\
\text { case }(\%)\end{array}$ & $\begin{array}{l}\text { Group B }(\mathrm{n}=40) \\
\text { case }(\%)\end{array}$ & $\begin{array}{l}\text { Group C }(\mathrm{n}=\mathbf{4 0}) \\
\text { case }(\%)\end{array}$ & $\begin{array}{l}\text { Group D (n=40) } \\
\text { case }(\%)\end{array}$ & $\begin{array}{l}\text { Total cases } \\
(\%)\end{array}$ \\
\hline Nausea & $3(7.5)$ & $2(5)$ & $5(12.5)$ & $4(7.5)$ & $14(8.7)$ \\
\hline Vomiting & $2(5)$ & $1(2.5)$ & $4(7.5)$ & $3(7.5)$ & $9(5.6)$ \\
\hline Shivering & $8(20)$ & $3(7.5)$ & $1(2.5)$ & $2(5)$ & $14(8.7)$ \\
\hline Diarrhea & Nil & $1(2.5)$ & $1(2.5)$ & $2(5)$ & $5(3.1)$ \\
\hline Headache & $2(5)$ & $3(7.5)$ & $2(5)$ & $2(5)$ & $10(6.25)$ \\
\hline Temperature $\geq 38^{\circ} \mathrm{C}$ & $8(20)$ & $1(2.5)$ & $2(5)$ & $2(5)$ & $13(8.1)$ \\
\hline Hypertension & $2(5)$ & Nil & $5(12.5)$ & $2(5)$ & $9(5.6)$ \\
\hline
\end{tabular}

\section{DISCUSSION}

The third stage of labor carries the highest risk of mortality and morbidity for the mother. It has been established that prophylactic administration of oxytocic agents in the active management of the third stage of labor could significantly reduce the incidence of primary
PPH from $18 \%$ to $5 \%$. In the present study 160 low risk term pregnant women were randomly given one oxytocic out of misoprostol, Oxytocin, Methylergometrine, PGF2 $\alpha$ in third stage of labor and using various parameters like blood loss, fall in hemoglobin, incidence of $\mathrm{PPH}$, duration of third stage of labor, use of additional oxytocics and side effects, the oxytocics were compared to each other.

Table 8: Comparison of average blood loss in all groups.

\begin{tabular}{|c|c|c|c|c|c|}
\hline & \multicolumn{4}{|c|}{ Oxytocic group: Blood loss in $\mathrm{ml}($ mean \pm SD) } & \multirow[t]{2}{*}{ p value } \\
\hline & $\mathbf{A}$ & B & $\mathbf{C}$ & D & \\
\hline Rao et $\mathrm{al}^{3}$ & $260.8 \pm 4.14$ & $280.4 \pm 47.5$ & $258.9 \pm 31.5$ & $221.4 \pm 40.6$ & $>0.05$ \\
\hline Sultana et $\mathrm{al}^{4}$ & 325.4 & 375 & & & $>0.05$ \\
\hline Parsons et $\mathrm{al}^{5}$ & 163.7 & 186.5 & & & $>0.05$ \\
\hline Vaid et $\mathrm{al}^{6}$ & 223.5 & & 194 & 227 & 0.567 \\
\hline Kumar S et $\mathrm{al}^{7}$ & & 188.9 & 194.75 & & NS \\
\hline Megha et al ${ }^{8}$ & $101.45 \pm 56.24$ & $118.60 \pm 70.72$ & $189.50 \pm 90.65$ & & Significant \\
\hline Alam et $\mathrm{al}^{9}$ & $183.18 \pm 9.70$ & $145.86 \pm 11.53$ & $164.02 \pm 9.36$ & & Significant $<0.05$ \\
\hline Present study & $320.75 \pm 233.54$ & $319.2 \pm 180.19$ & $322.5 \pm 196.06$ & $318.5 \pm 124.68$ & 0.99 \\
\hline
\end{tabular}


As we have already seen in results that there is no significant difference in mean blood loss in all groups similar results were seen in studies done by Rao et al,
Sultan et al, Parson et al, Vaid et al and Kumar S et al. ${ }^{3-7}$ Only study done by Megha et al and Alam et al shows significant difference in blood loss. ${ }^{8,9}$

Table 9: Comparison of difference in mean (pre and post-delivery) haemoglobin in all groups.

\begin{tabular}{|c|c|c|c|c|c|}
\hline & \multicolumn{4}{|c|}{ Oxytocic group: Difference in hemoglobin gm \% pre and post-delivery (mean \pm SD) } & \multirow[t]{2}{*}{ P value } \\
\hline & A & B & C & D & \\
\hline Parsons et $\mathrm{al}^{5}$ & 1.19 & 1.16 & & & 0.8 \\
\hline Afolabi et al $^{10}$ & 0.3 & 0.4 & & & 0.5 \\
\hline Kumar $\mathrm{S}$ et $\mathrm{al}^{7}$ & & 1.18 & 0.89 & & NS \\
\hline Alam et $\mathrm{al}^{9}$ & 0.38 & 0.28 & 0.35 & & $>0.05$ \\
\hline Present study & $1.54 \pm 1.01$ & $1.7 \pm 0.83$ & $1.66 \pm 0.98$ & $1.59 \pm 0.58$ & 0.84 \\
\hline
\end{tabular}

In the present study the change in pre and post-delivery mean haemoglobin was $1.54 \pm 1.01,1.7 \pm 0.83,1.66 \pm 0.98$ and $1.59 \pm 0.58$ respectively. The difference was not statistically significant. Similar results were seen in Parson et al, Afolabi et al, Kumar S et al and Alam et al. $5,7,9,10$

Table 10: Comparison of duration of third stage of labour in all groups.

\begin{tabular}{|c|c|c|c|c|c|}
\hline & \multicolumn{4}{|c|}{ Oxytocic group: Duration of third stage of labor in minutes } & \multirow[t]{2}{*}{ P value } \\
\hline & $\mathbf{A}$ & B & $\mathbf{C}$ & D & \\
\hline Rao et $\mathrm{al}^{3}$ & 6.1 & 6.3 & 6.2 & 6.4 & NS \\
\hline Sultana et $\mathrm{al}^{4}$ & 4.49 & 5 & & & NS \\
\hline Parsons et $\mathrm{al}^{5}$ & $6.9 \pm 6.1$ & $6.2 \pm 4.6$ & & & NS \\
\hline Afolabi et $\mathrm{al}^{10}$ & 4.5 & 4.6 & & & 0.22 \\
\hline Megha et $\mathrm{al}^{8}$ & $6.128 \pm 1.563$ & $6.411 \pm 1.589$ & $7.191 \pm 3.545$ & & Significant \\
\hline Alam et $\mathrm{al}^{9}$ & $6.47 \pm 1.51$ & $5.13 \pm 1.91$ & $6.16 \pm 1.85$ & & Significant \\
\hline Present study & $4.92 \pm 1.8$ & $4.85 \pm 2.52$ & $4.82 \pm 2.13$ & $4.9 \pm 2.1$ & 0.99 \\
\hline
\end{tabular}

In the present study the mean duration of third stage of labour in Group A, B, C and D was 4.925 \pm 1.89 , $4.85 \pm 2.52,4.825 \pm 2.13$ and $4.9 \pm 2.1$ minutes respectively. The difference was statistically non-significant. Similarly, no significant difference was seen in Rao et $\mathrm{al}^{3}$, Sultana et al, Parson et al and Afolabi et al but in study done by Alam et al there was significant difference between group $\mathrm{A}$ and $\mathrm{B}$ and Group $\mathrm{A}$ and $\mathrm{C}$ but no significant difference between group $\mathrm{B}$ and C. ${ }^{3-5,9,10}$ However, in study done by Megha et al the difference between the duration of the third stage of labor was significant between the misoprostol and methylergometrine groups with a $\mathrm{p}$ value of $<0.05$. $^{8}$

Table 11: Comparison of occurrence of PPH in all groups.

\begin{tabular}{|c|c|c|c|c|c|}
\hline & \multicolumn{4}{|c|}{ Oxytocic group: Occurrence of PPH } & \multirow[t]{2}{*}{ P value } \\
\hline & $\mathbf{A}$ & B & $\mathbf{C}$ & D & \\
\hline Rao et $\mathrm{al}^{3}$ & $15 \%$ & $17.5 \%$ & $10 \%$ & & NS \\
\hline Parsons et $\mathrm{al}^{5}$ & $3 \%$ & $7 \%$ & & & 0.58 \\
\hline Vaid et $\mathrm{al}^{6}$ & $12.12 \%$ & & $17.91 \%$ & $19.4 \%$ & 0.49 \\
\hline Megha et $\mathrm{al}^{8}$ & $1 \%$ & & $1 \%$ & & NS \\
\hline Present study & $17.5 \%$ & $12.5 \%$ & $15 \%$ & $5 \%$ & NS \\
\hline
\end{tabular}


In the present study the number of patients who had postpartum haemorrhage were $17.5 \%, 12.5 \%, 15 \%$ and $5 \%$ in groups $\mathrm{A}, \mathrm{B}, \mathrm{C}$ and $\mathrm{D}$ respectively. So maximum number of cases are from group A which may be because of variable onset of action of misoprostol but statistically there is no significant difference. Similar results were seen in studies done by Rao et al, Parson et al, Vaid et al and Megha et al. .,5,6,8 $^{2}$

Table 12: Comparison of patients requiring additional oxtocics in all groups.

\begin{tabular}{|c|c|c|c|c|c|}
\hline & \multicolumn{4}{|c|}{ Oxytocic group: Number of patients requiring additional oxytocics } & \multirow[t]{2}{*}{ P value } \\
\hline & A & B & $\mathbf{C}$ & D & \\
\hline Rao et $\mathrm{al}^{3}$ & 6.1 & 6.3 & 6.2 & 6.4 & Not significant \\
\hline Sultana et $\mathrm{al}^{4}$ & 4.49 & 5 & & & Not significant \\
\hline Parsons et $\mathrm{al}^{5}$ & $6.9 \pm 6.1$ & $6.2 \pm 4.6$ & & & Not significant \\
\hline Afolabi et $\mathrm{al}^{10}$ & 4.5 & 4.6 & & & 0.22 \\
\hline Kumar $\mathrm{S}$ et $\mathrm{al}^{7}$ & & 8 & 8 & & Not significant \\
\hline Megha et $\mathrm{al}^{8}$ & $1 \%$ & $3 \%$ & $7 \%$ & & Not significant \\
\hline Alam et $\mathrm{al}^{9}$ & $4(3.6 \%)$ & $2(1.8 \%)$ & None & & Not significant \\
\hline Present study & $45 \%$ & $17.5 \%$ & $22.5 \%$ & $15 \%$ & Significant \\
\hline
\end{tabular}

Table 13: Comparison of side effects in all groups.

\begin{tabular}{|c|c|c|c|c|c|c|}
\hline & Side Effect & \multicolumn{4}{|c|}{ Oxytocic group: Number of patients having side effects $(\%)$} & \multirow{2}{*}{ P value } \\
\hline & & A & B & $\mathbf{C}$ & D & \\
\hline \multirow{6}{*}{ Rao et $\mathrm{al}^{3}$} & Nausea & 5 & 7.5 & 35 & 25 & $<0.05$ \\
\hline & Vomiting & 5 & 5 & 32.5 & 35 & $<0.05$ \\
\hline & Shivering & 32.5 & 15 & 7.5 & 0 & $<0.05$ \\
\hline & Diarrhea & 5 & 0 & 0 & 52.5 & $<0.05$ \\
\hline & Headache & 5 & 0 & 10 & 12.5 & NS \\
\hline & Fever & 15 & 0 & 0 & 5 & NS \\
\hline \multirow[t]{2}{*}{ Sultana et $\mathrm{al}^{4}$} & Shivering & 6.19 & 1.05 & & & $<0.01$ \\
\hline & Diarrhea & 1.9 & 1.05 & & & $<0.5$ \\
\hline \multirow{4}{*}{ Afolabi et al ${ }^{10}$} & Nausea & 4.1 & 0 & & & \multirow{4}{*}{ NS } \\
\hline & Vomiting & 0 & 0 & & & \\
\hline & Shivering & 4 & 2 & & & \\
\hline & Fever & 0 & 0 & & & \\
\hline \multirow{5}{*}{ Alam et $\mathrm{al}^{9}$} & Nausea & & & & & \\
\hline & Vomiting & $6(5.4 \%)$ & & \multicolumn{2}{|c|}{$5(4.5 \%)$} & \\
\hline & Shivering & $2(1.8 \%)$ & & & & \\
\hline & Fever & & & & & \\
\hline & HTN & & & $2(1.8$ & & \\
\hline \multirow{3}{*}{ Kumar et $\mathrm{al}^{7}$} & Vomiting & & $0.5 \%$ & $15 \%$ & & \multirow{3}{*}{ NS } \\
\hline & Leg Cramp & & 0 & $7.5 \%$ & & \\
\hline & Chest pain & & $1.5 \%$ & $2.5 \%$ & & \\
\hline \multirow{6}{*}{ Megha et $\mathrm{al}^{8}$} & Nausea & 0 & $1 \%$ & $23 \%$ & & \multirow{6}{*}{ Significant } \\
\hline & Vomiting & $1(1 \%)$ & $3 \%$ & $10 \%$ & & \\
\hline & Shivering & $23(23 \%)$ & 0 & $3 \%$ & & \\
\hline & Fever & $11(11 \%)$ & $1 \%$ & 0 & & \\
\hline & Headache & & & 0 & & \\
\hline & HTN & & & $2 \%$ & & \\
\hline \multirow{7}{*}{ Present study } & Nausea & 7.5 & 5 & 12.5 & 10 & \multirow{7}{*}{ NS } \\
\hline & Vomiting & 5 & 2.5 & 7.5 & 7.5 & \\
\hline & Shivering & 20 & 7.5 & 2.5 & 5 & \\
\hline & Diarrhea & 0 & 2.5 & 2.5 & 7.5 & \\
\hline & Headache & 5 & 7.5 & 7.5 & 5 & \\
\hline & Fever & 20 & 2.5 & 5 & 5 & \\
\hline & Hypertension & 5 & 0 & 12.5 & 5 & \\
\hline
\end{tabular}


In the present study the number of patients requiring additional oxytocics were $45 \%, 17.5 \%, 22.5 \%$ and $15 \%$ in group A, B, C and D respectively and the difference was significant. As we can see $45 \%$ patients from group A require additional oxytocics which could be due to variable onset of action of misoprostol. But other studies did not show significant difference in need of additional dose of oxytocics.

In the present study hypertension was more common with Methylergometrine whereas shivering and fever was more common with misoprostol and diarrhea was seen more commonly in PGF2 $\alpha$ group. All these side effects were self-limiting and did not require any medication. In Rao et al nausea and vomiting were more common with methergin and PGF2 $\alpha$ and shivering and fever were with misoprostol and diarrhea with PGF $2 \alpha$ same as present study. ${ }^{3}$ In study done by Sultana et al shivering was more common with misoprostol compared to Oxytocin and the difference was significant similar results were found by Alam et al and Afolabi et al. ${ }^{4,9,10}$ An $\mathrm{h}$ alos in study done by Megha et al in misoprostol group the main side effects were shivering $23 \%$ and fever $11 \% .^{8}$ Misoprostol induced shivering occurred in immediate postpartum period and disappeared by itself. Shivering was sometimes associated with fever which recovered spontaneously after 1-2 hours

\section{CONCLUSION}

Study concluded that all uterotonics are equally advantageous in prevention of postpartum hemorrhage, but administrating the oxytocics depends upon its storage, route of administration, side-effects, contraindication and cost, hence Inj. Oxytocin is ultimate drug of choice in skilled hand due to its definite onset of action while Misoprostol can be used as complimentary drug because of variable onset of action but definitive duration of action.

Also, Tab Misoprostol can be used as primary drug in unskilled hands, due to its ease of administration, stability at room temperature, non-requirement of syringes, needles. In Methylergometrine to be administered after ruling out contraindication and Inj. PGF $2 \alpha$ is not that costeffective. Diarrhea is the common side effect with PGF2 $\alpha$, hypertension with Methylergometrine and shivering with fever is common with Misoprostol and all are self-limiting.

Funding: No funding sources Conflict of interest: None declared

Ethical approval: The study was approved by the Institutional Scientific and Research Committee

\section{REFERENCES}

1. WHO: Health topics-maternal health, WHO, 2011 Available at: http://www.who.int/topics/maternal health/en/.

2. Abalos E. Active management of third stage of labour. RHL Commentary. The WHO Reproductive Health library, Geneva: World Health Organization 2007.

3. Rao SB, Fonseca M, Ajmera S, Dhanajayan B, Badhwar VR. Is oral Misoprostol a promising alternative to standard oxytocic in the third stage of labor. Available at: http://www.bhj.org/journal /2008-4401-Jan/org-30htm. Accessed on 8/14/2008.

4. Sultana N, Khatun M. Misoprostol versus oxytocin in the active management of third stage of labor. J Bangladesh Coll Phys Surg. 2007;25:73-6.

5. Parson SM, Walley RL, Crane JMG, Mathews K, Hutchens D. Rectal Misoprostol versus oxytocin in the management of the third stage of labor. J Obstet Gynaecol Can. 2009;29(9);711-8.

6. Vaid A, Dadhwal V, Mittal S, Deka D, Misra R, Sharma JB, et al. A randomized controlled trial of prophylactic sublingual misoprostol versus intramuscular methylergometrine versus intramuscular 15-methyl PGF2 $\alpha$ in active management of third labour. Arch Gynecol Obstet. 2009;280:893-7.

7. Kumar S. A comparative study of ergometrine with oxytocin in controlling third stage blood loss-a randomized control trial. Sch J App Med Sci. 2013;1(5):595-9.

8. Sharma M, Kaur P, Kaur K, Kaur A, Kaur PK, Kaur MM. A comparative study of oxytocin/ misoprostol/ methylergometrine for active management of the third stage of labor. J Obstet Gynecol India. 2014;64(3):175-9.

9. Alam A, Shyam P, Goswami S. A comparative study of efficacy of oxytocin, methylergometrine and misoprostol in prevention of post-partum haemorrhage. Int $\mathbf{J}$ Reprod Contracept Obstet Gynecol. 2017;6(5):1960-4.

10. Afolabi EO, Kuti O, Orji EO, Ogunniyi SO. Oral misoprostol versus intramuscular oxytocin in the active management of third stage of labor. Singapore Med J. 2010;51(3):207-11.

Cite this article as: Gadappa N, Sharma D, Gavit Y. Comparative study of various oxytocics in management of third stage of labour. Int J Reprod Contracept Obstet Gynecol 2018;7:4035-41. 